\title{
PERUBAHAN SOSIAL BUDAYA MASYARAKAT PEDESAAN PASCA REVOLUSI HIJAU
}

\author{
Adam Saleh \\ Dosen Fakultas Ushuluddin, Adab dan Dakwah Institut Agama Islan Negeri (IAIN) Palu \\ adamsaleh@iainpalu.ac.id
}

\begin{abstract}
It is assumed that changes in village community will become even clearer if related to changes in village society at this time. Changes in society will look good in the fields of education, economics, social relations and other fields. Modernization is a change in society that moves from traditional conditions or from pre-modern society to modern society. The process of change was driven by various community efforts in fighting for their hopes and ideals, namely changing lives and existing livelihoods for the better. General characteristics of modernization are related to the fields of social social traditions, population science and technology and social mobility. The various fields are proceeding so as to achieve new patterns of behavior that are manifested in the life of modern society. Major changes that have taken place since the post-green revolution, villages in Southeast Asia have undergone fundamental changes. Rural life and the fulfillment of the needs of life of rural people in Southeast Asia have undergone a fundamental change, can no longer assume that the fulfillment of rural life needs are obtained from agriculture, nor can it assume that rural people face and expect their future in the field agriculture, these events affect each other or the interconnection between rural and urban areas, such as increased movement of rural people to cities or vice versa (urbanization and migration), the shift from agriculture to non-agriculture (agrarianindustrial transformation), as well as increased aspirations and education (social mobility Another thing that seems to change is lifestyle in the form of material, in this case related to household appliances, vehicles and communication tools.
\end{abstract}

Key words: Social culture, rural communities, after the green revolution,

\footnotetext{
Abstrak

Perubahan masyarakat desa yang diasumsikan bahwa akan semakin jelas jika dikaitkan perubahan masyarakat desa pada saat ini. Perubahan
} 
masyarakat akan nampak baik di bidang pendidikan, bidang ekonomi, pergaulan sosial kemasyarakatan dan bidang-bidang lainnya. Modernisasi merupakan perubahan masyarakat yang bergerak dari keadaan tradisional atau dari masyarakat pra modern menuju kepada masyarakat modern. Proses perubahan itu didorong oleh berbagai usaha masyarakat dalam memperjuangkan harapan dan cita-citanya, yaitu perubahan kehidupan dan penghidupan yang ada menjadi lebih baik. Karakteristik umum dari modernisasi adalah menyangkut bidang tradisi sosial kemasyarakatan, ilmu pengetahuan dan teknologi kependudukan dan mobilitas sosial. Berbagai bidang tersebut berproses sehingga mencapai pola-pola prikelakuan baru yang terwujud pada kehidupan masyarakat modern. Perubahan besar yang terjadi sejak pasca revolusi hijau, desadesa di Asia Tenggara telah mengalami perubahan-perubahan yang mendasar. Kehidupan perdesaan dan pemenuhan kebutuhan hidup orang-orang desa di Asia Tenggara telah mengalami perubahan yang mendasar, tidak bisa lagi berasumsi bahwa pemenuhan kebutuhan hidup di pedesaan didapatkan dari pertanian, juga tidak bisa lagi berasumsi bahwa orang-orang pedesaan menghadapi dan mengharapkan masa depannya pada bidang pertanian, kejadian tersebut saling mempengaruhi atau adanya interkoneksitas antara pedesaan dan perkotaan, seperti meningkatnya pergerakan orang desa ke kota atau sebaliknya (urbanisasi dan migrasi), pergantian dari pertanian ke non pertanian (transformasi agraris-industri), serta meningkatnya aspirasi dan pendidikan (mobilitas sosial. Hal lain yang terlihat berubah adalah gaya hidup berupa kebendaan, dalam hal ini terkait dengan alat-alat rumah tangga, kendaraan dan alat komunikasi.

Kata kunci: Sosial budaya, masyarakat pedesaan, pasca revolusi hijau.

\section{Pendahuluan}

Modernisasi merupakan perubahan masyarakat yang bergerak dari keadaan tradisional atau dari masyarakat pra modern menuju kepada masyarakat modern. Proses perubahan itu didorong oleh berbagai usaha masyarakat dalam memperjuangkan harapan dan cita-citanya, yaitu perubahan kehidupan dan penghidupan yang ada menjadi lebih baik. Karakteristik umum dari modernisasi adalah menyangkut bidang tradisi sosial kemasyarakatan, ilmu pengetahuan dan teknologi kependudukan dan 
mobilitas sosial. Berbagai bidang tersebut berproses sehingga mencapai pola-pola perikelakuan baru yang terwujud pada kehidupan masyarakat modern. ${ }^{1}$ Salah satu bidang yang dimasuki oleh modernisasi ini adalah bidang pertanian. Bidang pertanian sejak dimasuki oleh modernisasi telah mengalami perubahan yang besar. Baik dari segi peralatan pertaniannya maupun dari sikap dan perilaku para petani di pedesaan.

Pertanian modernisasi ini ditandai dengan pengggunaan alat-alat pertanian modern, baik penggunaan bibit unggul, penggunaan irigasi, penggunaan mesin-mesin, penggunaan pupuk maupun penggunaan obat pemberantas hama. Teknologi pertanian modern inilah yang mempengaruhi kehidupan masyarakat desa, terutama ekonomi dan pergaulan sosialnya. Pembangunan pedesaan, terutama penggunaan ekonomi dibidang pertanian membawa dampak terhadap kehidupan sosial budaya masyarakat. Setiap perubahan dalam satu lembaga akan mempengaruhi perubahan-perubahan dibidang lainnya. Pada lembaga-lembaga tersebut selalu terkait proses saling mempengaruhi secara timbal balik. ${ }^{2}$

Perubahan besar yang terjadi sejak pasca revolusi hijau, desa-desa di Asia Tenggara telah mengalami perubahan-perubahan yang mendasar. Kehidupan perdesaan dan pemenuhan kebutuhan hidup orang-orang desa di Asia Tenggara telah mengalami perubahan yang mendasar, tidak bisa lagi berasumsi bahwa pemenuhan kebutuhan hidup di pedesaan didapatkan dari pertanian, juga tidak bisa lagi berasumsi bahwa orang-orang pedesaan menghadapi dan mengharapkan masa depannya pada bidang pertanian, kejadian tersebut saling mempengaruhi atauadanyainterkoneksitas antara pedesaan dan perkotaan, seperti meningkatnya pergerakan orang desa ke kota atau sebaliknya (urbanisasi dan migrasi), pergantian dari pertanian ke non pertanian (transformasi agraris-industri), serta meningkatnya aspirasi dan pendidikan (mobilitas sosial). ${ }^{3}$

Perubahan masyarakat desa yang diasumsikan bahwa akan semakin jelas jika dikaitkan perubahan masyarakat desa pada saat ini.Perubahan masyarakat akan nampak

\footnotetext{
${ }^{1}$ Abdul Syani, 2002.Sosiologi; Skematika, Teori dan Terapan, Jakarta: Bumi Aksara. ${ }^{2}$ S. Soekanto. 1990, Sosiologi Suatu Pengantar, Jakarta: PT.Raja Grafindo Persada ${ }^{3}$ Rigg, Jonathan. 2001. More Than The Shoil: Rural Change in Southeast Asia, Prentice Hall
} 
baik di bidang pendidikan, bidang ekonomi, pergaulan sosial kemasyarakatan dan bidang-bidang lainnya.Pada bidang pendidikan, masyarakat Desa banyak yang menyekolahkan anak-anaknya diperguruan tinggi di kota-kota besar. Menyekolahkan anak diperguruan tinggi merupakan kebanggaan bagi keluarga dan menjadikan sebuah prestasi bagi keluarga tersebut. Semakin banyak anak-anaknya yang sekolah di perguruan tinggi menunjukan keluarga tersebut memiliki status sosial yang cukup bagus.Bidang lainnya yang mengalami perubahan adalah pekerjaan penduduk. Penduduk Desa biasanya bergerak dibidang pertanian, akan tetapi setelah terjadi modernisasi pertanian, masyarakat telah mengalami perubahan dalam lapangan pekerjaan. Pekerjaan yang dilakukan sekarang bervariasi, ada yang menjadi petani, pedagang, tukang sopir, membuka bengkel, tukang cukur, pegawai, beternak dan pekerjaan lainnya. Seiring dengan itu lahan-lahan pertanian yang ada semakin sempit, karena di samping digunakan untuk membangun rumah, juga tanah-tanah yang ada semakin di kuasai oleh penduduk yang mempunyai modal besar. Petani-petani yang ada cenderung menjual tanah miliknya pada penduduk yang memiliki modal besar, masyarakat cenderung menjadi buruh tani atau mencari pekerjaan di luar pertanian, dan banyak yang keluar daerahnya untuk mencari pekerjaan tersebut, bahkan ada yang keluar negeri atau sebagai tenaga kerja Indonesia (TKI)

Bidang lainnya lagi yang cepat mengalami perubahan adalah bidang pergaulan sosial, terutama keberadaan anak perempuan. Pada awalnya masyarakat pada umumnya sangat menjaga hubungan antara anak laki-laki dan perempuan, utamanya anak perempuan. Anak perempuan yang masih gadis akan dipingit oleh orang tuanya di rumah, jika mereka ingin keluar maka mereka harus ditemani oleh muhrimnya dengan pengawalan yang sangat ketat. Anak perempuan tidak boleh mererima tamu yang bukan muhrimnya, jika yang bertamu anak muda yang menginginkan anaknya, maka yang melayani tamu adalah orang tuanya, mereka bisa diberikan kebebasan untuk bergaul dan saling mengenal satu sama lain setelah menikah. Akan tetapi budaya seperti ini hampir selurunya hilang, karena masyarakat mengalami perubahan. 
Hal lain yang terlihat berubah adalah gaya hidup berupa kebendaan, dalam hal ini terkait dengan alat-alat rumah tangga, kendaraan dan alat komunikasi seperti telepon seluler, hampir seluruh keluarga memiliki HP terutama yang mempunyai anak-anak yang masih remaja. Mereka bisa ganti-ganti HP. Tipe HP merupakan pristise bagi anakanak muda. Demikian juga dengan kendaraan, banyak masyarakat memiliki motor walaupun motor kredit untuk jadi ojek. Demikian juga alat informasi berupa TV dan VCD.

Alat-alat transportasi dan alat-alat informasi seperti yang ada sekarang initelah membantu masyarakata untuk mempercepat beralihnya gaya hidup masyarakat dalam era modernisasi. Dengan kata lain bahwa gaya hidup masyarakat Desa menuju gaya hidup masyarakat Kota. Hal inilah yang dikatakan bahwa telah terjadi perubahan besar dari masyarakat yang tradisional menuju masyarakat modern.

\section{Pengertian Modernisasi}

Modernisasi adalah suatu perubahan-perubahan yang saling tergantung yang menguasai masyarakat-masyarakat industry. Kata modernisasi sebagai transformasi secara menyeluruh, dari masyarakat tradisional atau masyarakat pra modern menuju masyarakat yang bercorak teknologi. Modernisasi ini diciptakan oleh jalannya sejarah dewasa ini, yang sebelumnya seringkali digunakan istilah Eropanisasi untuk menunjukan adanya pengaruh Perancis di Syria, Libanon, dan pengaruh Inggris di Mesir dan Jordan. ${ }^{4}$ Makna kata ini, kelihatannya berbeda dari pandangan ahli-ahli yang ada, namun pada intinya, kata modernissai ini mengandung arti yang sama yaitu bermakna perubahan. Perubahan yang dimaksud adalah perubahan masyarakat, dari masyarakat tradisional menuju masyarakat modern.

Modernisasi tidak sama artinya dengan semua perubahan sosial, akan tetapi modernisasi sungguh mencakup perubahan-perubahan sosial, struktur, maupun kultural yang paling nampak besar-besaran, yang meliputi bagian-bagian penting dunia. Revolusi besar telah berlangsung di beberapa kawasan, termasuk revolusi pertanian, industri kota,

${ }^{4}$ NormaLong. 1987. Sosiologi pembangunan pedesaan, Jakarta: PT. Bina Aksara 
teknologi, keluarga, politik, dan demografi, dan yang mulai muncul di dua pertiga bagian dunia yang masih terbelakang merupakan proses modernisasi yang integral.Perubahan-perubahan yang terjadi di masyarakat tidak semuanya akibat modernisasi, karena ada perubahan yang tidak termasuk dalam konteks modernisasi, misalnya perubahan yang diakibatkan oleh peristiwa-peristiwa alam seperti gempa bumi, banjir, dan peristiwa-peristiwa alam lainnya.

Perubahan yang terjadi karena modernisasi selalu berkonotasi kearah positif, seperti perubahan yang terjadi di bidang pertanian. Modernisasi pertanian membawa dampak untuk meningkatkan perekonomian masyarakat, dan meningkatkan mutu hidup masyarakat, terutama di pedesaan. Perubahan ekonomi masyarakat ini akan mempengaruhi kehidupan di bidang lainnya. Proses modernoisasi lebih terletak pada tingkat kehidupan individu, antara lain perubahan sikap dan pola kelakuan yang berdasarkan pada prinsip atau nilai tertentu, seperti perubahan dari orientasi kepada askripsi atau nilai tertentu, seperti perubahan dari (achieve ment). Dimensi psikologi, seperti yang terdapat pada bidang kesadaran, sering dipandang sebagai faktor sangat mendasar yang menjadi landasan bagi perubahan, sikap dan keterampilan. Akhirnya, perubahan itu akan mengalami kristalisasi atau institusionalisasi, dengan perkataan lain muncul lembaga-lembaga baru. ${ }^{5}$ Proses modernisasi ini lebih terletak pada kehidupan individu di masyarakat. Perubahan-perubahan yang terjadi mengarah kepada nilai-nilai tertentu yang terjadi mengarah kepada nilai-nilai tertentu seperti nilai spiritual mengarah kepada nilai material, nilai kebersamaan menuju nilai individu, proses-proses seperti ini mengkristal di tengah-tengah masyarakat.

Masyarakat modern adalah masyarakat yang mengagungkan IPTEK, kehidupan material menonjol, sikap individualistik tinggi, penghargaan tinggi pada prestasi, dan secara psikologis mereka emosional, selalu cemas dan tingkat kecurigaan tringgi. ${ }^{6} \mathrm{Ciri}$-ciri masyarakat modern, seperti dikemukakan ${ }^{7}$ ini telah nampak di masyarakat sekarang,

${ }^{5}$ Nasikun, 1992, Protes Perubahan Sosial di Desa Jawa, Yogyakarta: Fakultas Ilmu Politik Universitas Gajah Mada, Yogyakarta Bekerjasama Dengan Rajawali Press.

${ }^{6}$ Madjid, Nurcholis. 1991. Islam Kemordenan dan Ke Indonesiaan, Bandung: Mizan.

${ }^{7} \mathrm{Ibid}$ 
bahkan ciri-ciri masyarakat modern seperti ini telah mempengaruhi kehidupan masyarakat desa. Dimana sebelumnya, masyarakat desa kental dengan adat istiadat dan rasa persaudaraan yang kuat, akan tetapi setelah masuknya modernisasi, maka nilai-nilai seperti itu sudah mulai pudar, dan yang menonjol adalah nilai-nilai materi dan nilai-nilai individu di tengah-tengah masyarakat.

Beberapa ciri-ciri masyarakat modern adalah sebagai berikut ${ }^{8}$ :

1. Bersedia menerima pengalaman-pengalaman baru

2. Mampu menyatakan pendapat bahkan membentuk opini tentang persoalan apa saja yang ada dalam masyarakat

3. Berorientasi pada perencanaan

4. Memiliki keyakinan untuk bekerja

5. Percaya bahwa segala hal, keadaan harus dapat diperhitungkan

6. Percaya pada harga diri dan keagungan harkat hidup dan keagunan manusia

7. Percaya pada ilmu dan teknologi

8. Percaya kepada keadilan dalam masyarakat.

\section{Modernisasi Pertanian}

Modernisasi pertanian adalah suatu perubahan-perubahan yang terjadi dibidang pertanian, dari pertanian tradisional menuju pertanian modern, dimana pertanian modern dicirikan dengan penggunaan mesin-mesin dan traktor sebagai pengganti pacul dan bajak, pemakaian bibit baru, dan pemakain pupuk-pupuk modern.Modernisasi pertanian ini ditandai dengan penggunaan alat-alat pertanian modern, baik penggunaan bibit unggul, penggunaan irigasi, penggunaan mesin-mesin, penggunaan pupuk, maupun penggunaan obat pemberantasan hama. Teknologi pertanian modern inilah yang mempengaruhi kehidupan masyarakat desa, terutama ekonomi dan pergaulan sosialnya. Perkembangan teknologi pertanian modern ini bermula dari gerakkan revolusi hijau (green revolution) di Amerika Serikat pada tahun 1860-an, yaitu dikembangkannya beberapa cara dan metode untuk menangani masalah kekurangan pangan di Amerika 
Serikat, dimana Amerika Serikat termasuk negara yang belum berkembang dan tergantung pada sektor pertanian. Revolusi hijau ini diterapkan di Indonesia pada tahun 1960-an dan sejak itulah Indonesia mengalami kemajuan ekonomi yang cukup berarti. Penerapan teknologi pertanian, sebagai tercermin dalam Revolusi Hijau bersamaan dengan tekanan pertumbuhan penduduk yang telah mempengaruhi perubahan pada bentuk penguasaan tanah dan hubungan kerja, tingkat upah, tingkat pendapatan, dan pola distribusi pendapatan penduduk desa. ${ }^{10}$

Empat proses yang cenderung mempengaruhi struktur sosial masyarakat tradisional yaitu: ${ }^{11}$

1. Modernisasi teknologi, membawa perubahan dari teknik-teknik tardisional kepada aplikasi ilmu pengetahuan

2. Pertanian komersial yang bercirikan pergeseran dari pertanian subsistem yang menuju pertanian untuk eksport, mengadakan spesialisasi terhadap yang akan diperdagangkan dan menggiatkan buruh upahan

3. Proses industrialisasi yang menggambarkan tradisi dari penggunaan kekuatan hewan dan manusia menuju penggunaan tenaga mesin

4. Urbanisasi yang meliputi perubahan-perubahan dimensi ekologi dan pergerakkan petani dan perkembangannya kearah pertumbuhan pusat-pusat kota.

Berdasarkan pendapat tersebut di atas, maka ada beberapa faktor yang penting yang mempengaruhi masyarakat desa yaitu modernisasi, teknologi pertanian komersial, industrialisasi, dan urbanisasi. Keempat hal inilah yang mempercepat proses perubahan pada masyarakat tradisional atau masyarakat desa yang ada.

\section{Perubahan Sosial}

${ }^{9}$ Daniel Lerner. 1993. Memudarnya Masyarakat Tradisional, Yogyakarta: Gajah Mada Universitas Press

${ }^{10}$ M. Idrus Abustam. 1991. Perubahan Sosial Budaya Pada Masyararakat Pedesaan di Pedesaan Sulawesi Selatan, Ujung Pandang, The Toyota Foundation: Yogya

11 Norma Long. 1987. Sosiologi pembangunan pedesaan, Jakarta: PT. Bina Aksara. 
Perubahan yang terjadi di masyarakat terbagi dua yaitu ada perubahan yang mengarah kepada kemajuan dan ada pula yang mengarah kepada kemunduran. Perubahan kearah kemajuan arti perubahan itu dapat memberikan kemanfaatan bagi kehidupan umat manusia, sedangkan kearah kemunduran bila dilihat dari kemunduran yang diakibatkan oleh perubahan tersebut.Perubahan sosial adalah perubahan dalam hubungan antar orang, organisasi atau komunitas ia dapat menyangkut stuktur sosial atau pola norma-norma serta peranan. Dengan demikian, istilah yang lebih lengkap adalah perubahan sosial kebudayaan. ${ }^{12}$ Perubahan yang terjadi bisa merupakan kemajuan dan mungkin juga suatu kemunduran. Unsur-unsur kemasyarakat yang mengalami perubahan biasanya adalah mengenai nilai-nilai sosial, norma-norma sosial, pola-pola penghidupan organisasi sosial, lembaga-lembaga kemasyarakat, startifikasi sosial, kekuasaan, tanggung jawab, kepemimpinan dan sebagainya. ${ }^{13}$

Perubahan yang serba multikompleks ini dengan sendirinya ada dua kemungkinan yaitu: ${ }^{14}$ (1) manusia menemukan sistem nilai dan falsafah hidup yang baru, dan (2) manusia tenggelam dalam persoalan-persoalan yang dihadapinya dan tidak dapat mengambil sikap (keputusan) terhadap keadaan baru. Akibat kedua inilah yang menyebabkan manusia mengalami frustasi bahkan apatis. Sebaliknya dimana manusia berhasil menemukan sistem nilai dan falsafah hidup baru, mencerminkan keadaan bahwa manusia berhasil mengatasi kritis yaitu berhasil mengambil keputusan. Untuk membuktikan adanya perubahan-perubahan yang terjadi di dalam masyarakat, maka dapat dibuktikan dengan adanya gejala-gejala seperti, depersonalisasi, adanya frustasi dan apatis (kelumpuhan) mental, pertentangan, dan perbedaan pendapat mengenai norma- norma susila yang sebelumnya dianggap mutlak, adanya pendapat generation gap (jurang pengertian antar generasi), dan lain-lain.

Perubahan-perubahan yang terjadi di masyarakat begitu cepatnya, bagaikan banjir yang melanda umat manusia dan terkadang umat manusia bingung sendiri

12 t Pudjiwati Sajogyo 1985. Sosiologi Pembangunan, Jakarta: Fakultas Pascasarjana IKIP Jakarta Bersama dengan Badan Koordinasi Keluarga Berencana Nasional

13Abdulsyani. 1994. Sosiologi dan Perubahan Masyarakat, Jakarta: PT. Dunia Pustaka Jaya.

${ }^{14}$ Susanto. 1985. Pengantar sosiologi dan Perubahan Sosial, Jakarta: Bina Cipta 
menghadapi perubahan-perubahan yang ada, dan bahkan ada yang frustasi menghadapi perubahan-perubahan. Perubahan sosial terjadi karena adanya perubahan dalam unsurunsur yang mempertahankan keseimbangan masyarakat seperti halnya perubahan dalam unsur-unsur geografis, biologis, ekonomi, dan kebudayaan. Perubahan masyarakat yang akan terjadi terus menerus dengan daya kecepatan yang berbeda. Perubahan sosial itu dapat dibedakan menjadi: ${ }^{15}$ (1) perubahan yang terjadi secara lambat (evolusi) dan perubahan secara cepat (revolusi), (2) perubahan yang pengaruhnya kecil dan perubahan pengaruhnya besar, dan (3) perubahan yang dikehendaki (intended-change) atau perubahan yang direncanakan (planned change) dan perubahan yang tidak dikendali (uniteded) atau perubahan yang tidak direncanakan. Penyebab lain dari perubahan sosial yaitu antara lain: ${ }^{16}$ ilmu pengetahuan (mental manusia), kemajuan teknologi, serta penggunaannya oleh masyarakat, komunikasi dan transportasi, urbanisasi, perubahan dan peningkatan harapan atau tuntutan manusia. Semua ini menyebabkan perubahan dan mempunyai akibat terhadap masyarakat yang disebut dengan "Rapid Sosial Change". Jadi, penyebab perubahan yang terjadi bermacam-macam. Ada perubahan yang diakibatkan oleh ilmu pengetahuan, ada perubahan yang diakibatkan oleh kemajuan teknologi, ada perubahan yang diakibatkan oleh komunikasi dan transportasi, dan ada juga diakibatkan oleh urbanisasi, kesemuanya ini bisa menyebabkan terjadinya perubahan sosial.

Menurut Soekanto (1990), membagi penyebab perubahan sosial berdasarkan sumber-sumbernya, yaitu dari masyarakat itu sendiri dan dari luar masyarakat penyebab perubahan yang bersumber dari masyarakat antara lain (1) bertambah dan berkurang penduduk, (2) penemuan-penemuan baru, (3) pertentangan (conflict), (4) terjadinya pemberontakan atau revolusi. Sedangkan penyebab perubahan yang bersumber dari luar masyarakat antara lain adalah (1) sebab-sebab bersumber dari lingkungan alam fisik yang ada di sekitar manusia, (2) pertumbuhan jumlah penduduk, dan (3) pertentangan (conflict).

\footnotetext{
${ }^{15}$ Soekanto. 1990.Sosiologi Suatu Pengantar, Jakarta: PT.Raja Grafindo Persada. ${ }^{16}$ Susanto. 1985. Pengantar sosiologi dan Perubahan Sosial, Jakarta: Bina Cipta.
} 
Perubahan-perubahan yang terjadi bisa timbul di dalam masyarakat, dan juga bisa diakibatkan di luar kelompok masyarakat yang ada. Perubahan yang datang di luar masyarakat bisa berupa ide-ide melalui mass media (TV, radio, dan surat kabar), dan juga alat-alat teknologi modern. Sedangkan perubahan yang timbul di dalam masyarakat, misalnya bertambah dan berkurangnya anggota masyarakat akibat kelahiran dan kematian, pertentangan atau konflik di antara anggota masyarakat yang ada dan penemuan-penemuan baru yang ada di masyarakat itu sendiri. Faktor-faktor yang mendorong individu untuk mencari penemuan baru adalah sebagai berikut: ${ }^{17}$ (1) keadaan dari orang perorangan akan kekurangan dalam kebudayaan, (2) kualitas dari ahli-ahli dalam suatu kebudayaan, dan (3) perangsangan bagi aktivitas-aktivitas penciptaan dalam masyarakat. Kecepatan perubahan dalam zaman modern menimbulkan masalah penting yang berkaitan dengan penyesuaian sosial, ada jenis penyesuaian sosial tersebut, yang pertama menyangkut adaptasi manusia pada kebudayaan atau lebih tepat mengadaptasikan kebudayaan pada manusia. Masalah kedua adalah penyesuaian pelbagai bagian kebudayaan, yang sebenarnya berarti mengadaptasikan kebudayaan pada manusia.

Penyesuaian kebudayaan adaptif pada kondisi-kondisi materil mencakup ruang lingkup proses-proses yang lebih luas dari pada tata kelakuan, kebiasaan dan lembagalembaga sosial, kebudayaan adaptif mencakup bagian-bagian non materil yang sesuai atau di adaptifkan pada kondisi-kondisi materiil.Beberapa bagian kebudayaan non materiil dengan sendirinya merupakan kebudayaan adaptif seperti aturan-aturan penggunaan alat-alat teknik sedangkan bagian lainnya tidak atau berkaitan langsung seperti agama. Keluarga memerlukan penyesuaian diri terhadap kondisi-kondisi materiil tertentu, tetapi aspek-aspek tertentu keluarga akan tetap demikian atau berlangsung secara konstan. Oleh karena itu, keluarga merupakan bagian budaya yang non materiil yang sebagian bersifat adaptif. Apabila kondisi-kondisi materiil berubah, maka perubahan-perubahan pada kebudayaan adaptif akan disesuaikan. Akan tetapi perubahan yang terjadi pada kebudayaan pada kebudayaan materiil.

${ }^{17}$ Abdulsyani. 1992. Sosiologi dan Perubahan Masyarakat, Jakarta: PT. Dunia Pustaka Jaya 


\section{Perubahan Sosial di Pedesaan Pasca Revolusi Hijau}

\section{Aktifitas Petani di Luar Pertanian dan Mobilitas Sosialnya}

Modernisasai pertanian memasuki wilayah pedesaan di Asia Tenggara, khususnya Indonesia sekitar tahun 1960-an, yang biasa di istilah oleh para pakar pedesaan sebagai revolusi hijau. Dan sejak dimasuki revolusi hijau, keadaan pedesaan terjadi perubahan. Perubahan pertama yang terjadi adalah perubahan ekonomi pedesaan, baru setelah itu terjadi perubahan di bidang lainnya. Perubahan salah satu bidang akan mempengaruhi bidang lainnya.Perubahan yang bisa terikat adalah adanya keluarga-keluarga petani yang beraktivitas mencari tambahan ekonomi di luar bidang pertanian. Keluarga petani membolehkan keluarganya menekuni aktivitas diluar pertanian adalah untuk mencari rezeki tambahan bagi keluarganya.

Isu keterlibatan keluarga-keluarga petani dalam aktivitas industri non pertanian yang membolehkan keluraga petani dalam skala kecil menekuni aktivitas tersebut. Dengan kata lain pertanian ditarik dalam proses industri, bukan hanya melalui alokasi dan penggantian, namun secara tidak langsung melalui pemasukan yang dihasilkan oleh rumah tangga petani dari aktivitas non petani. Kombinasi petani dan non petani inilah yang menjelaskan gaya pegas yang mengejutkan dari khususnya sebagai mata pencaharian tambahan. ${ }^{18}$

Para pakar perubahan pedesaan di negara-negara maju khususnya di Inggris yang yang menegaskan jangkauan pedesaan sebagai suatu yang dapat diidentifikasikan dan bertalian secara sosial dan ekonomi, telah dipatahkan.Ruang pedesaan baru ditandai dengan tanda keanekaragaman dan persaingan antara orang-orang dengan minat yang berbeda-beda, hal ini menunjukan dua hal alasan, yaitu: ${ }^{19}$

1. Masyarakat pedesaan telah menyimpang dan muncul perserikatan baru serta persaingan antara produsen dan konsumen dalam lingkup pedesaan. Para petani (produsen) telah melihat bahwa kekuasaan politik mereka relatif semakin

\footnotetext{
${ }^{18}$ Jonathan Rigg. 2001. More Than The Shoil: Rural Change in Southeast Asia, Prentice Hall

${ }^{19}$ Mosher, A. T. 1983. Menggerakkan dan Membangun Pertanian, Syarat-Syarat Pembangunan dan Modernisasi, Jakarta: CV. Yasaguna
} 
berkurang sepanjang era perlindungan pangan dan kemunduran bidang pertanian, sebagaimana konsumen telah melihat posisi mereka yang memberi pengaruh. Kebanyakan penduduk pedesaan tidak berhubungan langsung dengan pertanian. Bagi mereka, wilayah pedesaan merupakan tempat rekreasi, perumahan dan konservasi. Pertanian mungkin memiliki pegangan tambahan bagi mereka, namun sebagai gagasan romantis atau kategori, bukan sebagai sistem produksi.

2. Alasan kedua, mengapa pedesaan sebagai sebuah kategori, menjadi semakin problematis karena interpenetrasi aktivitas perkotaan. Mobilitas orang-orang pedesaan membuat mereka bekerja di tempat yang jauh dari kediaman mereka, apakah atas dasar harian atau untuk waktu yang lama (pergerakan lingkar/musiman). Kemunduran juga merupakan persoalan, meskipun hal ini agak lebih lazim pada negara maju penduduk perkotaan memanfaatkan daerah pinggiran sebagai tempat rekreasi. Hasilnya, mata pencaharian pedesaan bergantung pada aktivitas yang ditempatkan tidak jauh dari pedesaan atau aktivitas non pertanian (industri) yang telah menjangkau daerah pinggiran.

Perubahan pedesaan ini dalam negara berkembang, konflik. Prinsip-prinsip pengetahuan sentral dibangun setelah perang, yang didahului oleh pasang surut proses restruktrurisasi pedesaan dan perkotaan yang dikendalikan secara ekonomi dan sosial. Perubahan ini dijelaskan dari sudut dua pergeseran utama. Perubahan horizontal, membawa kepada sebuah proses konter urbanisasi seperti yang diungkapkan Masden sebagai sebuah proses yang telah mendefinisikan kembali hubungan antara kota dan daerah pedesaan. Dan juga perubahan vertikal terhadap pengaruh produsen dan proses hulu dan hilir, serta agen pusat, baik nasional maupun internasional. Hal yang mungkin paling penting dari perubahan-perubahan ini adalah sentralitas lingkup pedesaan. Wilayah pedesaan di negara-negara berkembang tidak lagi di dominasi sektor marjinal dan dihuni oleh orang-orang yang terlibat dalam aktivitas marjinalnya. Namun perubahan ini bukan karena pertanian yang tiba-tiba menjadi hal penting baru, namun karena wilayah pedesaan telah dijangkau oleh orang-orang baru dan aktivitas-aktivitas yang lebih bersifat politik dan punya bobot ekonomi. 


\section{Meraih Masa Depan: Hasrat, Mobilitas, dan Modernisasi}

Dalam membicarakan dua isu tentang aspirasi dengan modernitas, maka akan lebih banyak membahas tentang dua faktor penting yang mendorong terjadinya perubahan pada masyarakat pedesaan, yakni faktor yang memikat, menarik dan yang mendorong manusia untuk menjadi seorang modern. Kebutuhan akan barang-barang telah ditentukan, begitupun dengan semakin meningkatnya keinginan, maka pola konsumsi juga akan ikut berubah. Kebutuhan akan ditentukan oleh praktek budaya dan norma-norma sosial yang berlaku. Pola konsumsi sangatlah erat kaitanya dengan isu-isu komunikasi spasial (menyangkut ruang) dan sosial manusia dan masyarakat berkomunikasi untuk menemukan kebutuhan konsumsi mereka, dengan melakukan komunikasi, maka akan terbentuk pola perilaku. Pada saat yang sama, pada mobilitas, komunikasi menjadikan pasar yang menyebar hingga kepelosok pedesaan. Masyarakat pedesaan dan produk-produk yang mereka hasilkan dapat di pasarkan lagi ke wilayah yang lebih luas.

Hasil penelitian itu menunjukan bahwa 99,5\% memilih pendidikan bagi anakanak hingga level dua sebagai kebutuhan, $97 \%$ menganggap lampu listrik sebagai kebutuhan, $83 \%$ memilih kipas angin listrik, $41 \%$ memilih jam tangan dan $21 \%$ memilih televisi sebagai kebutuhan. Faktor penelitian lain di Thailand, penelitian ini menunjukan bahwa pada kebanyakan daerah pedesaan sekarang ini, menganggap televisi sebagai barang kebutuhan. ${ }^{20}$ Sementara di beberapa tempat sepeda motor dan truk pengangkut tumpahan digolongkan sebagai kebutuhan. Pendidikan, pengalaman akan kota dan kehidupan kota itu sendiri, serta pesan-pesan konsumerisme yang disiarkan oleh televisi, radio, surat kabar dan majalah, semuanya sangat berperan dalam memunculkan sebuah kultur baru dalam masyarakat yang paling tepat untuk digambarkan modernis dan konsumeris.

\section{Pendidikan}

${ }^{20}$ Mubyanto, 1989. Pengantar Ekonomi Pertanian, Jakarta: Lembaga Pendidikan dan Penerangan Ekonomi dan Sosial (LP3ES) 
Penekanan pada pentingnya pendidikan di Indonesia benar-benar mulai tertanam setelah tahun 1945, dan semakin meningkat dalam setiap dekade. Pendidikan berubah secara fundamental selama tahun 1970-an karena beberapa alasan: layanan pendidikan meningkat secara drastis. Budaya modernitas, yang merupakan pusat komponen pendidikan, mulai berdampak pada pengambilan keputusan, dan nilai ekonomis pendidikan secara luas, pekerjaan non pertanian meningkat disaat pertanian tidak diperdulikan. Pada tahun 1960-an tidak ada penduduk elit dataran tinggi yang ingin anak-anak mereka meninggalkan desa untuk melanjutkan pendidikan; pada tahun 1980an banyak yang melakukannya.Survai yang dilakukan di Luzow Tengah menunjukan peningkatan dramatis, jumlah anak-anak masyarakat petani pada di bagian utara Manila Filipina yang masuk Perguruan Tinggi (pendidikan tinggi). Pada tahun 1986 hanya 7 \% dari pekerja pertanian menempuah pendidikan pada perguruan Tinggi, di tahun 1990, 12 \% dan tahun 1994, 20 \%. Peningkatan luar biasa ini dilakukan, sebagian untuk meningkatkan kekayaan keluarga dan sebagian untuk meningkatkan pendidikan untuk mendapatkan pekerjaan non pertanian. Hal ini mendorong orang tua untuk berinvestasi lebih banyak dengan menyekolahkan anak-anak mereka, terutama melanjutkan ke jenjang perguruan tinggi. ${ }^{21}$

Kehidupan masyarakat pedesaan kontemporer di Asia Tenggara, membuktikan bahwa orang-orang pedesaan, hampir tanpa kecuali, mengakui pentingnya pendidikan. Hal ini diakui secara universal bahwa jalan untuk kemajuan melibatkan beberapa langkah pendidikan dan semakin banyak langkah pendidikan yang kita tempuh, maka akan semakin baik. Begitu banyak orang yang haus akan pendidikan sehingga mendorong orang tua bersedia mengorbankan banyak hal untuk memastikan anak-anak mereka mendapatkannya. Keluarga meninggalkan kampung halaman dan pindah ke daerah perkotaan untuk bisa mendapatkan sekolah yang lebih baik di sana. Anak-anak dikirim untuk tinggal bersama kerabat di kota-kota yang jauh, ibu-ibu menjual perhiasan emas dan bapak-bapak menggadaikan atau menjual tanah untuk mengumpulkan uang untuk biaya sekolah, nilai ekonomi seorang anak dikorbankan, pendapatan dari investasi

\footnotetext{
${ }^{21}$ Menurut Jonathan Rigg, bahwa
} 
pertanian yang produktif dialihkan untuk kebutuhan pendidikan seperti membayar seragam, peralatan sekolah, buku dan transportasi, dan mereka harus mengurangi pengeluaran konsumsi dalam keluarga. Kadang-kadang dapat terlihat bahwa penekanana pada pendidikan ini adalah mengorbankan segala-galanya sehingga merugikan dari sudut pertimbangan yang lebih luas. ${ }^{22}$

\section{Sosial Budaya Masyarakat Petani}

Petani dengan ketetapan yang mutlak sangat susah karena batasnya memang kabur pada ujung kenyataan sosial itu sendiri. Suatu sejarah subordinasi kepada kelas tuan tanah diakui dan diperkuat dengan hukum kekhususan kultural yang tajam dan sampai tingkat tertentu kekhususan dengan fakta dalam pemilikan tanah merupakan ciriciri pokok yang membedakan seorang petani.Masyarakat petani terbagi bermacammacam, ada masyarakat petani sawah, ada masyarakat petani ladang, ada masyarakat petani tambak, dan ada juga masyarakat petani kebun. Mengingat masyarakat petani ini cukup unik, maka mendefinisikannya juga cukup susah. Olehnya itu, tidak ada kesepakatan di antara para ahli tentang definisi masyarakat petani, karena mengingat keunikan masyarakat petani itu sendiri, di dalam kehidupan sehari-hari.

Ada beberapa kesulitan berkaitan dengan sifat khusus masyarakat petani yang mempunyai ciri-ciri: (1) mempunyai hubungan dengan tanah dengan ciri spesifik produksi pertanian berakar pada keadaan khusus petani, (2) usaha tani keluarga merupakan satuan dasar pemilikan, produksi, dan konsumsi dan kehidupan petani, (3) kepentingan pokok pekerjaan dalam menentukan kedudukan sosial, peranan dan kepribadian petani dikenal secara baik oleh masyarakat bersangkutan, (4) struktur sosial desa merupakan keadaan khusus bagi daerah tertentu dan waktu tertentu, (5) masyarakat petani merupakan sebuah kesatuan sosial pra industri yang memindahkan unsur-unsur spesifik struktur sosial-ekonomi dan kebudayaan lama ke dalam masyarakat kontemporer. ${ }^{23}$ Sehubungan dengan masyarakat petanimenekankan bahwa, setiap upaya pembatasan pengertian petani memang haruslah bersifat relasional dan struktural dari

22 Menurut Jonathan Rigg 2001. More Than The Shoil: Rural Change in Southeast Asia, Prentice Hall

23 Nasikun. 1992, Protes Perubahan Sosial di Desa Jawa, Yogyakarta: Fakultas Ilmu Politik Universitas Gajah Mada, Yogyakarta Bekerjasama Dengan Rajawali Press 
pada hanya berdasarkan pada mata pencaharian. Foster melihat bahwa meskipun petani merupakan suatu bagian dari suatu peradaban, memproduksi bahan makanan bagi kehidupan perkotaan, mendukung kelas politik tertentu, penguasa, agama, dan kaum elit berpendidikan lainnya. ${ }^{24}$ Dalam hal ini masyarakat petani tidak seharusnya dipahami sebagai sistem utuh dalam dirinya sendiri, yang mandiri, dalam memenuhi kebutuhannya sebagaimana dipakai dalam menunjuk masyarakat lokal primitif, melainkan masyarakat yang sudah menjalin hubungan dan dipengaruhi oleh masyarakat yang sudah menjalin hubungan dan dipengaruhi oleh masyarakat luar, baik itu kota maupun negara.Begitupun dalam hal sosial budaya masyarakat petani, para ahli belum ada kesepakatan tentang hal itu, yang ada hanyalah kesepakatan sosial budaya masyarakat secara umum.

Sosial budaya atau kebudayaan dalam pengertian yang luas yaitu meliputi segala aspek kehidupan manusia dengan unsur-unsurnya yaitu: ${ }^{25}$ (1) sosial atau pergaulan hidup, (2) ekonomi, hubungan manusia dengan materi, (3) politik, hubungan manusia dengan kekuasaan untuk mengatur sosial ekonomi, (4) pengetahuan, hubungan manusia dengan kebenaran, (5) teknik, hubungan manusia dengan kerja, (6) seni, hubungan manusia dengan bentuk-bentuk yang menyenangkan, (7) agama, hubungan manusia dengan yang kudus, yang bersifat gaib.Mengingat masyarakat petani adalah bagian dari masyarakat secara umum, maka unsur-unsur sosial budaya yang terdapat diatas terdapat juga di masyarakat petani, yang walaupun harus diakui, bahwa dalam masyarakat petani ada hal-hal yang spesifik dibanding masyarakat umum lainnya.

\section{Strata Sosialnya}

Masyarakat petani pedesaan dapat dibedakan menjadi tiga strata yaitu: (1) buruh tani murni (tidak memiliki dan menguasai tanah), (2) buruh tani merangkap sebagai petani penggarap (menyewa dan menyekap), dan (3) buruh tani merangkap sebagai

\footnotetext{
${ }^{24} \mathrm{Ibid}$

${ }^{25}$ Alfian, 1986. Transformasi Sosial Budaya Dalam Pembangunan Nasional, Jakarta: Penerbit Universitas Indonesia (UI Press)
} 
pemilik atau penggarap juga sebagai penyekap atau penyewa. ${ }^{26}$ Pembagian masyarakat petani menurut Sawit ini, dari semua strata yang ada tetap memakai istilah buruh tani, baik yang memiliki tanah, yang menguasai tanah, maupun yang tidak memiliki dan menguasai tanah. Beliau tidak membedakan mana yang bertindak sebagai buruh dan mana sebagai majikannya, semuanya dianggap sebagai buruh tani.

Strata petani ada tiga, yaituPertama, strata bawah, yaitu memilki tanah pertanian 0,5 hektar ke bawah, kedua, petani menengah, yaitu petani yang memiliki lahan 0,5-1 hektar, dan ketiga, adalah petani kelas atas yaitu petani yang memilki lahan lebih dari 1 hektar. Walaupun antara Breman dan Abustam, memiliki kesamaan dalam membagi tiga strata petani, baik strata atas, menengah, maupun strata bawah, namun kedua-duanya memiliki perbedaan yang mendasar tentang luasnya kepemilikan lahan dari masingmasing strata dan juga antara kedua berbeda pengertian di dalam menempati strata yang ada. Breman sendiri mencampur adukan antara pemilik lahan dengan penyewa, sedangkan Abustam hanya melihat strata yang ada berdasarkan kepemilikan lahan dari masing-masing strata, baik strata atas, menengah, maupun strata bawah. ${ }^{27}$ Klasifikasi petani berdasarkan pemikiran luas lahan dikaitkan dengan sumber pendapatan, menjadi strata yaitu petani gurem dan buruh tani dengan luas pemilikan kurang dari 0,2 hektar, petani kecil 0,25-0,5 hektar, dan petani besar lebih 0,5 hektar. ${ }^{28}$

Pembagian strata petani oleh para ahli di atas kelihatan dari redaksinya berbedabeda, namun pada intinya sepakat bahwa petani itu terbagi kepada tiga strata, walaupun ukurannya berbeda-beda pula.

\section{Usaha Tani}

Usaha tani merupakan himpunan dari sumber-sumber alam yang terdapat di tempat itu yang diperlukan untuk produksi pertanian seperti: tubuh tanah, sinar matahari, bangunan-bangunan yang didirikan di atasnya, dan sebagainya. Setiap usaha

${ }^{26}$ Sawit, H. M. dan D. Triono. 1984. Pola Musiman dan Tingkah Laku Rumah Tangga Buruh Tani dalam Pasar Tenaga Kerja di Pedesaan Jawa, Studi Dinamika Pedesaan

${ }^{27}$ M. Idrus Abustam. 1991. Perubahan Sosial Budaya Pada Masyararakat Pedesaan di Pedesaan Sulawesi Selatan, Ujung Pandang, The Toyota Foundation: Yogya

${ }^{28}$ Sayogyo, 1987. Lapisan Masyarakat yang Paling Lemah di Pedesaan jawa, Jakarta: LP3ES 
dalam mengingatkan pertanian seperti halnya di daerah irigasi haruslah; ${ }^{29}$ (a) mengubah panen produksi pertanian, (b) mengubah corak masing-masing usaha tani, (c) mengubah hubungan antara biaya dan pemakaian usaha tani, dan (d) mengubah perilaku petani. Dalam menjalankan usaha taninya, setiap petani memegang dua peranan yakni sebagai juru tani (cultivator) dan sekaligus sebagai seorang pengelola (manajer). Petani sebagai juru tani yaitu memelihara tanaman dan hewan guna mendapatkan hasil-hasilnya yang bermanfaat. Sedangkan peranan petani sebagai pengelola (manajer) yaitu apabila keterampilan bercocok tanam sebagai juru tanam pada umumnya yakni keterampilan tangan, otot, dan mata, maka keterampilan sebagai pengelola mencakup kegiatan pikiran didorong oleh kemauan.Dalam melakukan usaha tani, petani membutuhkan modal, tenaga kerja, dan pengetahuan pertanian ${ }^{30}$. Faktor utama produksi utama dalam bertani adalah tanah atau lahan yang dapat dipakai untuk melakukan usaha bercocok tanam. Faktor kedua adalah tenaga (energi) manusia yang sering juga ditunjang oleh energi hewan, atau bahkan tenaga (energi) ciptaan manusia seperti mesin-mesin. Untuk mendapatkan mesin-mesin dan perangkat lainnya diperlukan faktor produksi ketiga berupa uang atau modal. ${ }^{31}$ Dengan demikian meningkatnya atau berkurangnya produksi pertanian amat berkaitan dengan ketiga faktor tersebut.

Dalam melakukan usaha tani, ada tiga faktor yang perlu diperhatikan yaitu; pertama, modal, kedua, tenaga kerja, dan ketiga, adalah pengetahuan tentang pengetahuan itu sendiri. Meningkat dan berkurangnya hasil produksi pertanian amat terkait dengan ketiga faktor tersebut. Olehnya itu jika ingin menjadi petani yang berhasil, maka diperlukan memahami ketiga faktor ini, baik tentang modal pertanian, tenaga kerja, maupun pengetahuannya.Petani dalam melakukan usaha taninya terbagi dua tipe, pertama, ada petani yang melakukan usaha tani karena ingin memenuhi kebutuhan rumah tangganya sendiri dan kedua, ada petani yang melakukan usaha taninya keperluan pasar

${ }^{29}$ Mubyanto, 1989. Pengantar Ekonomi Pertanian, Jakarta: Lembaga Pendidikan dan Penerangan Ekonomi dan Sosial (LP3ES)

${ }^{30}$ Ardi, M. Sila, A. R. dan Aras, A. H., 2000. Faktor-Faktor Yang Mempengarubi Perilaku Petani Dalam Meningkatkan Kwalitas Lingkungan Hidup di Daerah Irigasi Propinsi Sulawesi Selatan, Makassar: Direktorat Jendral Pendidikan Tinggi, Departemen Pendidikan dan Kebudayaan.

${ }^{31}$ Sugihan, B. T. 1997. Sosiologi Pedesaan (Suatu Pengantar), Jakarta: PT. Raja Grafindo Persada. 
atau dijual. Dan khususnya bagi petani sekarang ini lebih banyak melakukan usaha taninya untuk keperluan pasar atau dijual dari pada petani yang melakukan usaha tani untuk keperluan rumah tangganya sendiri. Hal ini cukup mempengaruhi petani dalam melakukan usaha taninya, baik cara berpikirnya maupun dalam perilakunya.

\section{Solidaritas Sosial}

Solidaritas sosial yaitu hubungan-hubungan dalam masyarakat yang mempunyai nilai-nilai positif, seperti persaudaraan, kekeluargaan, kerukunan, dan kegotongroyongan. Warga dalam suatu masyarakat pedesaan mempunyai hubungan yang lebih erat dan lebih mendalam dibandingkan hubungan mereka dengan warga masyarakat desa yang lainnya. Sistem kehidupan biasanya berkelompok atas dasar sistem kekeluargaan. ${ }^{32}$ Hubungan-hubungan kekeluargaan dan kekerabatan yang kental ini terdapat di masyarakat pedesaan dan kekerabatan mereka saling tolong menolong, bantu membantu. Hal ini bebeda dengan penduduk kota yang hidup cenderung bersifat egois dan individual antara satu dengan yang lainnya di masyarakat, sehingga antara masyarakata kota dengan masyarakat desa mempunyai pola pikir, sikap, dan perilaku yang berbeda-beda pula dalam kehidupan kesehariannya.

Kehidupan tolong menolong itu nampak dalam kehidupan masyarakat di Indonesia di pedesaan, misalnya dalam kehidupan di rumah tangga dalam menyiapkan dan melaksanakan pesta perkawinan, sunatan, kecelakaan dan kematian. ${ }^{33}$ Hal ini berlangsung secara suka rela. Dan disamping ada tolong-menolong diantara sesama, maka ada lagi kebiasaan masyarakat desa yaitu bergotong-royong. Hal ini adalah aktivitas kerjasama antara sejumlah besar warga desa untuk menyelesaikan suatu pekerjaan tertentu yang dianggap berguna bagi kepentingan umum, seperti membuat jalan atau memperbaiki jalan, membangun suatu proyek untuk kepentingan umum dan kegiatan lainnya.Kegiatan-kegiatan kemasyarakatan, seperti perkawinan, sunatan, acara selamatan lainya diselesaikan secara bersama-sama. Mereka tanpa melalui undangan resmi seperti di kota, datang membantu dan meringankan beban keluarga yang berhajat,

\footnotetext{
${ }^{32}$ Soejono Soekanto. 1990, Sosiologi Suatu Pengantar, Jakarta: PT.Raja Grafindo Persada.
} 
mereka membawa sesuatu, baik uang, beras, maupun keperluan hajatan lainnya. Hal ini mereka lakukan ikhlas tanpa dipaksa oleh siapapun di dalam melakukannya. Dan jika ada kesulitan keluarga mereka akan bermusyawarah di antara keluarga untuk mengatasi persoalan yang ada. Itulah ciri-ciri masyarakat desa seperti di Indonesia ini. Masyarakat Desa sering sekali ditandai oleh keterlibatan kegiatan-kegiatan pertanian dan ikatanikatan keluarga yang sangat erat. Hubungan antara pribadi yang ada di antara para keluarga yang sangat erat diantara para anggotanya sangat kuat dan ditandai pola-pola perilaku tradisional. Gaya hidup orang-orang yang tinggal di desa pada umumnya informal, dan masyarakat-masyarakat semacam ini terbukti sangat memegang teguh kebiasaan-kebiasaan atau adat istiadat.

\section{Kesimpulan}

Pertanian modernisasi ini ditandai dengan pengggunaan alat-alat pertanian modern, baik penggunaan bibit unggul, penggunaan irigasi, penggunaan mesin-mesin, penggunaan pupuk maupun penggunaan obat pemberantas hama. Teknologi pertanian modern inilah yang mempengaruhi kehidupan masyarakat desa, terutama ekonomi dan pergaulan sosialnya. Pembangunan pedesaan, terutama penggunaan ekonomi dibidang pertanian membawa dampak terhadap kehidupan sosial budaya masyarakat. Setiap perubahan dalam satu lembaga akan mempengaruhi perubahan-perubahan dibidang lainnya. Pada lembaga-lembaga tersebut selalu terkait proses saling mempengaruhi secara timbal balik. Perubahan masyarakat akan nampak baik di bidang pendidikan, bidang ekonomi, pergaulan sosial kemasyarakatan dan bidang-bidang lainnya.Modernisasi merupakan perubahan masyarakat yang bergerak dari keadaan tradisional atau dari masyarakat pra modern menuju kepada masyarakat modern. Proses perubahan itu didorong oleh berbagai usaha masyarakat dalam memperjuangkan harapan dan cita-citanya, yaitu perubahan kehidupan dan penghidupan yang ada menjadi lebih baik. Karakteristik umum dari modernisasi adalah menyangkut bidang tradisi sosial kemasyarakatan, ilmu pengetahuan dan teknologi kependudukan dan mobilitas sosial. Berbagai bidang tersebut berproses sehingga mencapai pola-pola 
perikelakuan baru yang terwujud pada kehidupan masyarakat modern. Perubahan besar yang terjadi sejak pasca revolusi hijau, desa-desa di Asia Tenggara telah mengalami perubahan-perubahan yang mendasar. Kehidupan perdesaan dan pemenuhan kebutuhan hidup orang-orang desa di Asia Tenggara telah mengalami perubahan yang mendasar, tidak bisa lagi berasumsi bahwa pemenuhan kebutuhan hidup di pedesaan didapatkan dari pertanian, juga tidak bisa lagi berasumsi bahwa orang-orang pedesaan menghadapi dan mengharapkan masa depannya pada bidang pertanian, kejadian tersebut saling mempengaruhi atau adanya interkoneksitas antara pedesaan dan perkotaan, seperti meningkatnya pergerakan orang desa ke kota atau sebaliknya (urbanisasi dan migrasi), pergantian dari pertanian ke non pertanian (transformasi agraris-industri), serta meningkatnya aspirasi dan pendidikan (mobilitas sosial. Hal lain yang terlihat berubah adalah gaya hidup berupa kebendaan, dalam hal ini terkait dengan alat-alat rumah tangga, kendaraan dan alat komunikasi seperti telepon seluler, hampir seluruh keluarga memiliki HP terutama yang mempunyai anak-anak yang masih remaja. Mereka bisa ganti-ganti HP. Tipe HP merupakan pristise bagi anak-anak muda. Demikian juga dengan kendaraan, banyak masyarakat memiliki motor walaupun motor kredit untuk jadi ojek. Demikian juga alat informasi berupa TV dan VCD.

\section{Daftar Pustaka}

Abdul Syani, 2002.Sosiologi; Skematika, Teori dan Terapan, Jakarta: Bumi Aksara. . 1994. Sosiologi dan Perubahan Masyarakat, Jakarta: PT. Dunia Pustaka Jaya.

Abustam. 1991. Perubahan Sosial Budaya Pada Masyararakat Pedesaan di Pedesaan Sulawesi Selatan, Ujung Pandang, The Toyota Foundation: Yogya

Affan Gaffar 1995. Modern dan Umat Islam Indonesia, ARA - AITA No. 32/TH, XI/1995

Alfian, 1986. Transformasi Sosial Budaya Dalam Pembangunan Nasional, Jakarta: Penerbit Universitas Indonesia (UI Press)

Ardi, M. Sila, A. R. dan Aras, A. H., 2000. Faktor-Faktor Yang Mempengarubi Perilaku Petani Dalam Meningkatkan Kwalitas Lingkungan Hidup di Daerah Irigasi Propinsi 
Sulawesi Selatan, Makassar: Direktorat Jendral Pendidikan Tinggi, Departemen Pendidikan dan Kebudayaan.

Daniel Lerner. 1993. Memudarnya Masyarakat Tradisional, Yogyakarta: Gajah Mada Universitas Press

Jonathan Rigg. 2001. More Than The Shoil: Rural Change in Southeast Asia, Prentice Hall Madjid, Nurcholis. 1991. Islam Kemordenan dan Ke Indonesiaan, Bandung: Mizan.

Mosher, A. T. 1983. Menggerakkan dan Membangun Pertanian, Syarat-Syarat Pembangunan dan Modernisasi, Jakarta: CV. Yasaguna

Mubyanto, 1989. Pengantar Ekonomi Pertanian, Jakarta: Lembaga Pendidikan dan Penerangan Ekonomi dan Sosial (LP3ES)

Nasikun, 1992, Protes Perubahan Sosial di Desa Jawa, Yogyakarta: Fakultas Ilmu Politik Universitas Gajah Mada, Yogyakarta Bekerjasama Dengan Rajawali Press.

Norma Long. 1987. Sosiologi pembangunan pedesaan, Jakarta: PT. Bina Aksara

Pudjiwati Sajogyo 1985. Sosiologi Pembangunan, Jakarta: Fakultas Pascasarjana IKIP Jakarta Bersama dengan Badan Koordinasi Keluarga Berencana Nasional

Sawit, H. M. dan D. Triono. 1984. Pola Musiman dan Tingkah Laku Rumah Tangga Buruh Tani dalam Pasar Tenaga Kerja di Pedesaan Jawa, Studi Dinamika Pedesaan

Sayogyo, 1987. Lapisan Masyarakat yang Paling Lemah di Pedesaan jawa, Jakarta: LP3ES

Soejono Soekanto. 1990, Sosiologi Suatu Pengantar, Jakarta: PT.Raja Grafindo Persada.

Soekanto, Soejono. 1990, Sosiologi Suatu Pengantar, Jakarta: PT.Raja Grafindo Persada

Soekanto. 1990. Sosiologi Suatu Pengantar, Jakarta: PT.Raja Grafindo Persada.

Sugihan, B. T. 1997. Sosiologi Pedesaan (Suatu Pengantar), Jakarta: PT. Raja Grafindo Persada.

Susanto. 1985. Pengantar sosiologi dan Perubahan Sosial, Jakarta: Bina Cipta 